\title{
OEDIPUS IN HAMLET
}

\begin{abstract}
Even though examining the psychology of fictional characters as that of a real person is often difficult, I believe it to be crucial for understanding deep, character-driven narratives, such as Shakespeare's Hamlet. In this paper, I will seek to take a closer look at the subtler mechanisms of Hamlet's psychology and motivation by applying the ideas of Freud and other thinkers, following a similar line of thought, to the analysis of this character. In Freud's work, Hamlet is perceived as an unaccomplished Oedipus. The main objective of this research will be to test Freud's hypothesis by closely examining Hamlet's constant delaying of his father's revenge, his resentment of Claudius mixed with sympathy and his disgust with Gertrude by applying methods of Freudian psychoanalysis, or, to be exact, the effect of a repressed Oedipus complex on his development as a character.
\end{abstract}

Key words: Oedipus complex, Hamlet, Freud, psychoanalysis

\section{Introduction}

In his legendary work Interpretation of Dreams, Freud explains Hamlet's personal conflict as stemming from the Oedipus complex (Freud 2010: 111). Although looking at a fictional character through the lens of Freud's psychoanalysis might seem counter-intuitive at first, such an approach may lead to a deeper understanding of both the play's central conflict as well as the concept of the Oedipus complex itself.

\section{Oedipus in Hamlet}

Freud believes that the reason for Hamlet's delay in killing his uncle, the man who murdered his father, might be the product of an Oedipus complex. According to Freud, Claudius epitomized Hamlet's repressed desires. Hamlet had two sinful wishes, both of which were fulfilled by his uncle (Freud 2010: 112). Claudius killed old King Hamlet and married Gertrude shortly after. Freud believes that these were Hamlet's unconscious desires, so he sees a reflection of himself in Claudius. This identification

${ }^{*}$ PhD candidate, Faculty of Philology, University of Belgrade, Studentski trg 3, 11000 Belgrade, Serbia; e-mail: emily_the_me@hotmail.com 
with the king could be what makes Hamlet so reluctant to avenge his father. If this is true, by killing Claudius, Hamlet would, in a way, kill part of himself, the part that wished to remove his father as an obstacle and marry his mother; the Oedipus in Hamlet. That is why he simply cannot do it, he cannot kill the person whose actions he feels as his own. And only when he knows his life is coming to its end, is he capable of killing the king.

To quote Freud: "In Oedipus Rex the basic wish-phantasy of the child is brought to light and realized as it is in dreams; in Hamlet it remains repressed, and we learn of its existence - as we discover the relevant facts in a neurosis - only through the inhibitory effects which proceed from it" (Freud 2010: 111). This would explain why we have no proof of it in the book as it is, because unlike Oedipus' desire, Hamlet's desire is not fulfilled, and we can only acknowledge it through examination of his behavior and his words.

"Hamlet's notorious inaction, inseparable from the play's non-classical interminability and its suspenseless delays, stems from the reflexivity of filial guilt, which turns violence in upon the subject and the text in melancholy masochism rather than unfolding outward in the dramatic realization (or discovery) of patricidal motives" (Reinhard Lupton and Reinhard 1993: 118). He destroys himself out of this fear and guilt that blossoms from profane thoughts. Hamlet cannot act, therefore he tortures himself with his extreme melancholia and self-reproach. He can face neither his incestuous desires nor his patricidal guilt, so he tries to repress both of them. This guilt he feels is powered by his inability to face the truth which he obviously cannot admit even to himself, and he is trapped by it. Our protagonist is afraid of his impure desires, and that fear, as any other, is what paralyzes every action.

One of the main hypotheses that Freud and his disciples support is the fact that Hamlet never provided any valid reason for his delay (Freud 2010: 111). This is why they believe that the reason was deeply rooted in his unconscious. We must also note that the basis of the Oedipal complex is not just desire for the mother, but in most cases also loathing towards the father. This is by no means true when it comes to Hamlet, quite the contrary, as we can see that the prince loves and respects his father. When comparing old King Hamlet to Claudius, not only does Hamlet show no signs of dislike, but with his words gives us proof that his father was very dear to him. However, psychoanalysts assure us that this too can be the product of an Oedipus complex. A child can repress his emotions so successfully that instead of feeling rivalry towards his father, he will develop feelings of excessive respect and even deep love.

When arguing that Hamlet might have repressed his Oedipal complex, Ernest Jones explains that certain mental processes are more likely to be repressed than 
others (Jones 1976: 58). The culture in which the individual is born and raised can influence this. That is to say, an individual will repress those mental processes that are perceived as improper by society. Hamlet is a contemplative character, and one would expect that at least he would understand his own nature, if no one else could, yet he does not. Jones believes that this is the product of repressed emotions (Jones 1976: 70). Hamlet's desires are hidden from all of us, including himself, in his unconscious.

Another possibility is that Hamlet's hatred towards Claudius is not merely envy of Claudius' fulfilling Hamlet's desires, but rather a transformed fear of his own incestuous urges and the product of it, i.e. the consequences which may result. Hamlet might have wondered about what might follow. What would he do after murdering Claudius? Would he take his place both on the throne and in his mother's bed? In Freud $>\mathrm{s}$ words "The loathing which should have driven him to revenge is thus replaced by selfreproach, by conscientious scruples, which tell him that he himself is no better than the murderer whom he is required to punish." (Freud 2010: 112). Hamlet hates Claudius, but even more than Claudius, he hates himself for resembling the king in those crucial features. That is the product of his unconscious identification with his uncle. The proof for all of this could be found in his continuous insistence upon Gertrude's incestuous remarriage, and the cruelty and disgust he shows every time he mentions it.

Hamlet is not only disgusted with the actions of his mother, he is a man completely disappointed with the world and its inhabitants. T. S. Eliot believes that Gertrude sparked this discontent in the first place (Eliot 1921: 92). If we take a look at the play we will notice that this is possibly true, for his first soliloquy is about his feeling of impurity: "Oh, that this too, too sullied flesh would melt, Thaw, and resolve itself into a dew" (Shakespeare 1995: 187). The sole reason for this abhorrence is of being her son, of having to call her his mother. He is repelled by the fact that his flesh sprouted from hers; angry with the fate that made him her kin. This he cannot escape. Eliot explains: "Hamlet is up against the difficulty that his disgust is occasioned by his mother, but that his mother is not an adequate equivalent for it; his disgust envelops and exceeds her" (Eliot 1921: 92). Gertrude is just the beginning, everything that follows this original disappointment makes him even more disgusted with the world. All that he learns about the world after this initial disappointment is bad, possibly worse than his mother's hasty remarriage to the man who killed her first husband. He compares her to an animal, he states that an animal would be more loyal than she is, and mourn longer than she has; showing just how immoral and inhuman her act is. Dower Wilson states: "His mother is a criminal, has been guilty of a sin which blots out the stars for him, makes life a bestial thing, and even infects his very blood. She has committed incest" (Wilson 1960: 39). This idea of a sin that is transferred from mother to offspring solely by birth is biblical in nature and it is the obvious remaining 
influence of the Church on the Elizabethans. Hamlet is ashamed of Gertrude and feels that his mother ruined not only the memory of his father, her husband, but also Hamlet, just by giving birth to him.

Although Hamlet is angry and disgusted with the acts of his mother, he is more similar to her than he would like to be. Hamlet feels Gertrude's incestuous desires as his own, and in this sense also identifies with her, probably because he has urges of the same kind towards her. But, the way Hamlet sees it, Gertrude is weak, because she gives in to temptation and sin, whereas he manages to resist it and hide it.

If it is the Oedipus complex that stops Hamlet from avenging his father, it is only logical that he fulfills his revenge at the very end of the play. Gertrude is already dead by that time. So, finally, there is nothing to stop him. The fears of his incestuous desire towards his mother are gone with her passing away, he is free of them. His motives are clear and are not the product of personal wishes. Hamlet is finally free from the guilt he had experienced up to that moment, because of his mother. He can focus on his revenge rather than on self-reproach, and only then does he succeed, he can kill Claudius, and feel guiltless for it, because he is acting on the command of the Ghost of his father. He has all the necessary proof that Claudius is the villain and he is not acting out of his passion, he is not its slave.

Freud further goes to connect the events that had occurred in Shakespeare's life before the writing of the play to its theme and the Oedipal complex. First of all, Shakespeare's father died shortly before Shakespeare wrote Hamlet. Freud uses this information to further establish his Oedipal theory and through it the problem of Hamlet's procrastination. At this time of mourning, Freud explains that Shakespeare relived his long-forgotten childhood feelings that he had towards his father, which are patricidal in nature (Freud 2010: 112). This idea allows an Oedipal reading. Furthermore, Shakespeare had a son whose name was Hamnet and who died at a very young age. Even though the name Hamnet with all its variations was rather common in Shakespeare's time, it is oddly similar to the name of the hero of this play. Shakespeare, therefore, represents both the father and the son in Oedipal readings. In his grieving moments, when he writes the play, he puts himself in the position of the son, grieving for his father, but he also takes the place of the father because, due to the similarity of these two names, he connects his own son with the prince. In addition to this, there is a story that Shakespeare played the Ghost of Hamlet's Father, which, if true, would confirm Freud's theory.

\section{Conclusion}

In this paper Hamlet's character and the reasons for his procrastination have been analyzed in accordance with the solutions provided by Sigmund Freud. Through 
closer examination of this theory, we have tried to move closer to the truth behind Hamlet's delay. Although we can never tell for certain that Hamlet's actions or the lack thereof originate in the Oedipus complex, this idea still may be fertile soil for further exploration as it provides a different perspective for understanding this work of literature.

\section{References}

Eliot, T. S. (1921). The Sacred Wood: Essays on poetry and criticism. New York: Alfred A. Knopf.

Freud, S. (2010). The Interpretation of Dreams. Charlotte: Information Age Publishing. Jones, E. (1976). Hamlet and Oedipus. New York: The Norton Library.

Reinhard Lupton, J. and K. Reinhard (1993). After Oedipus: Shakespeare in Psychoanalysis. London: Cornell University Press.

Shakespeare, W. (1995). Hamlet, edited by Harold Jenkins. London: Routledge.

Wilson, J. D. (1960). What Happens in Hamlet. Cambridge: Cambridge University Press. 